\title{
Cystic pneumocystosis in a patient with AIDS
}

Pneumocistose cística em paciente com SIDA

Rodrigo Juliano Molina ${ }^{1}$, Cristina Hueb Barata ${ }^{1}$ and Dalmo Correia ${ }^{1}$

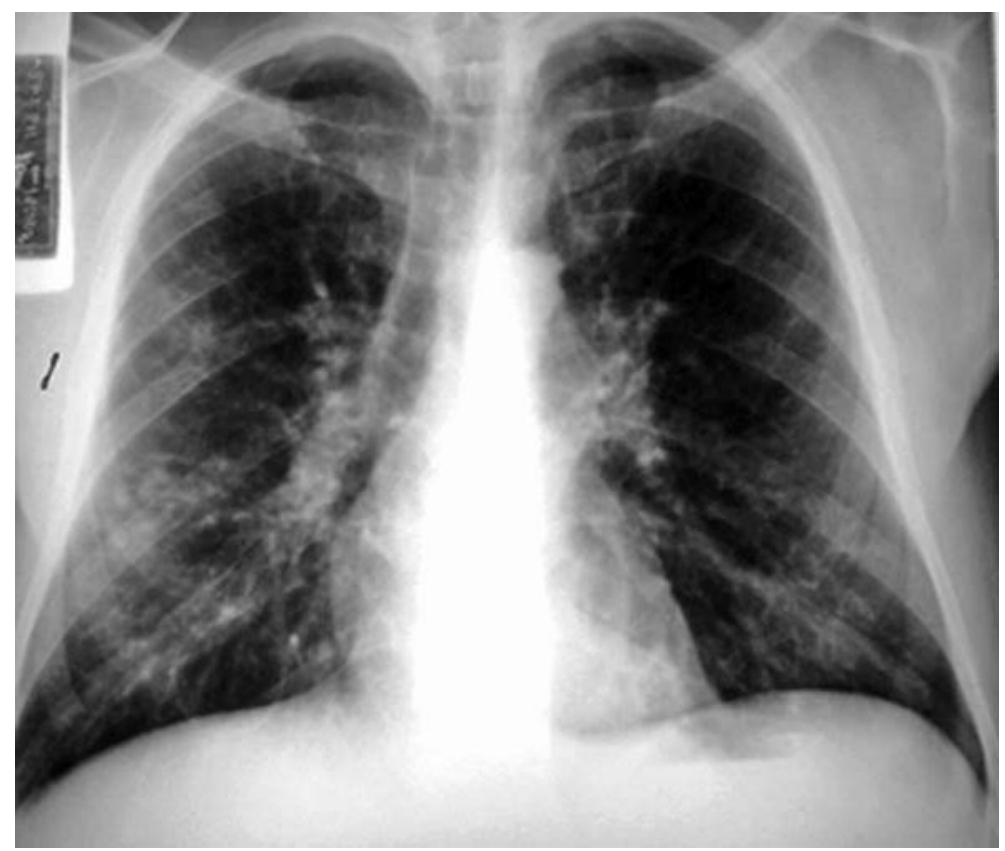

A

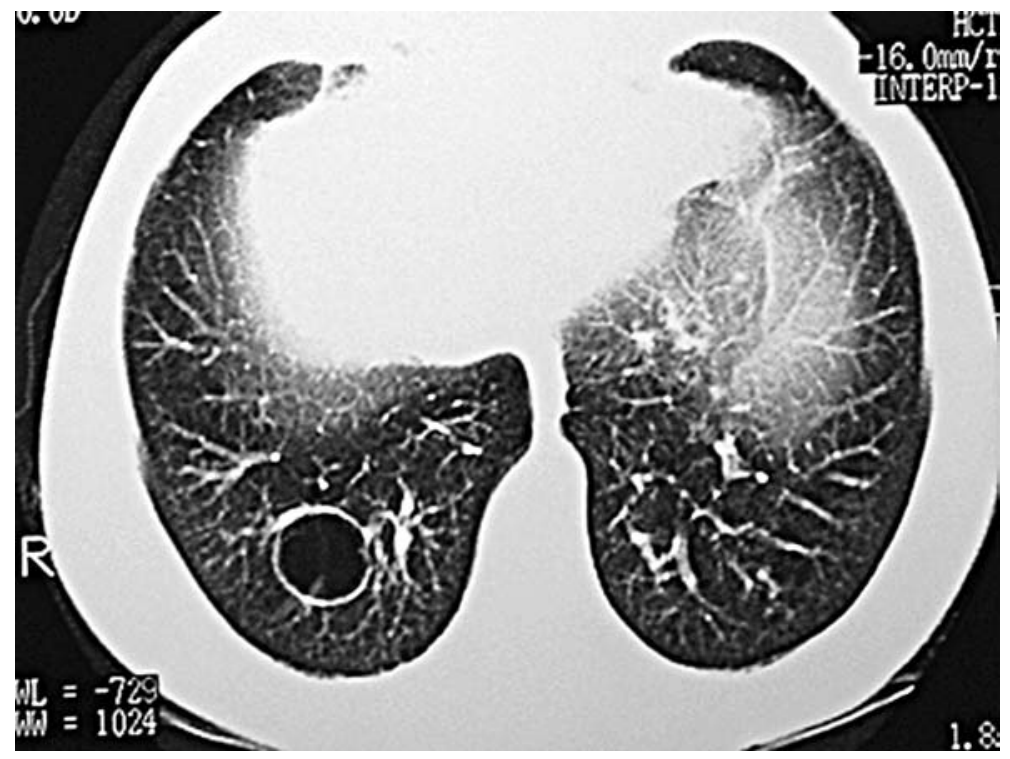

B

1. Disciplina de Doenças Infecciosas e Parasitárias, Universidade Federal do Triângulo Mineiro, Uberaba, MG. Address to: Prof. Dalmo Correia. Av. Getúlio Guaritá 130. Caixa Postal 118, 38025-440 Uberaba, MG. Tel: 5534 3318-5255

e-mail: dalmo@mednet.com.br

Recebido para publicação em: 03/08/2007

Aceito em: 21/08/2007 
A 34-year-old man was hospitalized on February 14, 2005, with fever of up to $39^{\circ} \mathrm{C}$ with several peaks over the course of the day. He also reported a persistent cough with slight production of yellowish sputum. He had sought the health services in his hometown and had been medicated for three days with amikacin, ceftriaxone and sulfamethoxazole-trimethoprim (SMX-TMP). Because there was no clinical improvement, he was referred to the Teaching Hospital of Universidade Federal do Triângulo Mineiro. He had had AIDS since July 1998, and had already presented clinical episodes of pneumocystosis, secondary syphilis and, as a comorbidity, moderate asthma. The CD4+ T lymphocyte count in February 2005 was 381 cells $/ \mathrm{mm}^{3}$ (51.1\%). He had given up treatment for HIV infection two months earlier. On physical examination, he presented diffuse wheezing and rales in the lower third of both lungs. His respiratory rate was 24 ; his heart rate was 76; and his arterial blood pressure was $130 / 80 \mathrm{mmHg}$. A chest $\mathrm{x}$-ray showed condensations in the base of the right lung (Figure A). Computed tomography of the chest showed tenuous groundglass opacity in both lung fields and multiple bilateral well-defined thin-walled cystic lesions in subpleural and medullary locations (Figure B - in a lateral view, a large, well defined cyst is demonstrated by CT scan - arrow). He was treated for pneumocystosis using SMXTMP. Bronchofibroscopy with alveolar lavage was performed, from which the anatomopathological examination showed structures compatible with Pneumocystis jiroveci. Highly active antiretroviral therapy (HAART) using the AZT/3TC/NFV scheme was administered and a good clinical response to treatment was observed. Cyst formation in the pulmonary parenchyma is unusual in patients with pneumocystosis. We have reported on the case of an AIDS patient who presented cystic lesions attributed to pneumocystosis.

0 paciente, de 34 anos, foi internado em 14/02/2005 com febre de até $39^{\circ} \mathrm{C}$, com a presença de vários picos ao longo do dia. Relatava, ainda, tosse persistente, pouco produtiva com escarro amarelado.
Procurou serviço de saúde em sua cidade natal sendo medicado por três dias com amicacina, ceftriaxona e sulfametoxazol-trimetoprima (SMX-TMP). Por não haver melhora clínica, foi encaminhado ao Hospital Escola da Universidade Federal do Triângulo Mineiro. Ele é portador do vírus HIV desde julho de 1998, já tendo apresentado, como intercorrências clínicas, pneumocistose, síflis secundária e, como co-morbidade, asma moderada. A contagem de linfócitos T CD4+ em fevereiro de 2005 foi de 381 células/ $/ \mathrm{mm}^{3}$ (51,1\%). Ele interrompera o tratamento para o HIV havia dois meses. Ao exame físico apresentava sibilos difusos e crepitações em terço inferior de ambos os pulmões. $\mathrm{FR}=24 \mathrm{irm} ; \mathrm{FC}=76 \mathrm{bpm} ; \mathrm{PA}=130 \mathrm{X} 80 \mathrm{mmHg}$. A radiografia simples do tórax mostrava consolidação em base pulmonar direita (Figura A). A tomografia computadorizada (TC) do tórax evidenciou opacidade tênue em vidro fosco distribuída em ambos os pulmões e múltiplas lesões císticas de paredes finas e bem definidas bilaterais de localização subpleural e medular (Figura B - a TC, em perfil, revela um cisto bem formado - seta). Ele foi tratado para pneumocistose com SMX-TMP. Submeteu-se à broncofibroscopia com lavado alveolar cujo exame anatomopatológico evidenciou estruturas compatíveis com Pneumocystis jiroveci. Recebeu o tratamento para o HIV com o esquema de AZT + 3TC + NFV e evoluiu bem. A formação de cistos no parênquima pulmonar não é freqüiente em pacientes com pneumocistose. Relatamos o caso de paciente com SIDA que apresentou lesões císticas atribuídas à pneumocistose.

\section{REFERENCES}

1. Frenkel JK. Pneumocystis. In: Binford CH, Connor DH (eds) Pathology of tropical and extraordinary diseases. Armed Forces Institute of Pathology, Washington, DC p. 303-307, 1976.

2. Pereira SA, Rodrigues DB, Correia D, Reis MA, Teixeira VP. Identification of infectious agents in the lungs in autopsies of patients with acquired immunodeficiency syndrome. Revista da Sociedade Brasileira de Medicina Tropical 35: 635-639, 2002.

3. Wakefield AE. Pneumocystis carinii. Brazilian Medicine Bulletin 61: 175-188, 2002. 